\title{
Russian nuclear accident opens up military complex
}

Moscow. The chemical explosion last week in a reprocessing tank in the Russian city of Tomsk-7 has also blown the cover of a formerly secret city that until recently did not officially exist.

The plutonium reprocessing plant is at the city of Tomsk-7, built in the 1940s to produce plutonium for Soviet nuclear weapons. It now emerges that three of the six reactors are still working. Soviet authorities had said the purpose of the plant was to provide fuel for civilian nuclear power plants. The city is situated on the Tom River bank about $20 \mathrm{~km}$ north of the Siberian town of Tomsk, which is 3,000 km east of Moscow.

The explosion occurred on 6 April in a stainless steel holding tank within minutes of the addition of nitric acid as a solvent. The explosion blew a reinforced concrete lid through the roof of the plant.

There is considerable debate about the contents of the tank and the potential threat to residents and to the environment from the radiation released in the explosion. The ministries in charge say that the tank contained uranium-235 and plutonium-237 but not plutonium-239, which is more toxic. That, however, implies that the nuclear fuel in the reactors contained no uranium-238, the chief constituent of natural uranium.

Alexei Yablokov, ecology and public health adviser to President Boris Yeltsin, says that he will ask the government "to conduct a thorough check of all potential radiation hazards in Russia, including military ones". Yablokov believes that Russian officials have underestimated the doses to which firefighters were exposed and that levels inside the building were many times higher than what was reported outside. One rescue worker is reported to be under treatment.

The initial official report, denied the following day, said that the solution con-

\section{Debris no hazard to space flights}

Munich. Space debris does not constitute a hazard to space missions, and it is neither technically practical nor economically feasible to remove the 7,000 objects in space left by earlier missions, according to 250 scientists from 17 countries who met last week in Darmstadt, Germany.

The participants agreed that prevention was the best approach and suggested ways to keep debris levels within safe limits, including boosting satellites into higher orbits at the end of their mission and reducing the amount of material that accompanies the intended payload into orbit. The group also agreed to continue monitoring the situation and to meet again in a few years.

A.A.

tained plutonium and uranium salts and that some amount of plutonium-237 and uranium-235 were released into the atmosphere. There were similarly conflicting reports about the existence of a cloud said to be moving toward a nearby town.

Viktor Mikhailov, minister for nuclear energy, said that plutonium has not been produced at Tomsk-7 in the past year. A subordinate contradicted his statement but said that no plutonium was released in the explosion. Lidiya Popova, an expert on nuclear physics at the Socio-Ecological Union, an environmental organization, who twice visited Tomsk-7 last year, says that plutonium-239 is common at military complexes such as Tomsk-7.

The accident occurred just before the seventh anniversary of the disaster at the Chernobyl nuclear power plant, but this 'nuclear spring' was announced within a few hours. It is also the first time that such an

\section{Japan increases share of Human Frontier awards}

Tokyo. Japan's scientists performed well in the latest round of awards from the Strasbourg-based Human Frontier Science Program (HFSP), winning more fellowships than scientists of any other country and trailing only the United States in the number of grant recipients. But the awards for international research on the brain and biological functions announced last week also show that Japan is the least popular destination for bright young scientists.

The Frontier programme, which this year has an annual budget of about US $\$ 40$ million provided largely by Japan, was established in 1989 on Japan's initiative with the backing of the seven Western summit nations (Japan, United States, Canada, United Kingdom, France, Germany and Italy) and the European Communities (EC). Applications for grants and fellowships, which are open to scientists around the world, are screened by international peer review.

Competition is severe: the 191 successful grant recipients represent only $12-13$ per cent of the applications, which require proposals from international teams of scientists. And more than 500 young scientists applied for the 152 long-term fellowships awarded this year.

The latest round (see table) shows that the United States once again has the largest number of grant participants, followed by Japan and Britain. In addition, six of the 42 principal scientists in charge of the international teams are Japanese, as are 35 of the 152 long-term postdoctoral fellows. But only one of the 152 fellows has chosen to work in Japan, with a majority choosing the United States and most of the rest headed for Europe.

event at a military nuclear plant was made public when it happened instead of months or years later.

Yelena Bonner, widow of Andrei Sakharov, says that the incident shows that "we need Western experts to assess the situation. The fact that this plant was producing secret weapons is the most worrying. International controls need to be increased." Others have said that the two accidents demonstrate that every part of the chain in handling nuclear material is important and that the state must tighten its control over the process.

Nevertheless, the average Russian citizen seems less concerned about the potential threat to public health posed by nuclear weapons than about the current economic crisis - in particular, last week the price of petrol was doubled, from 40 to 80 rubles, an increase that Yeltsin has promised to overrule.

Monthly Nature, Moscow

Japanese government officials and scientists are embarrassed by the low level of interest in Japan, citing problems with language and housing as well as deteriorating facilities at government laboratories and universities. Applicants may also be deterred by restricted career opportunities for foreign scientists and a lack of information about Japan's research organizations.

David Swinbanks

\begin{tabular}{lrr}
\hline \multicolumn{3}{c}{ HFSP scorecard } \\
\hline Country & & \\
\hline Canada & Researchers & Leaders \\
\hline France & 11 & 4 \\
Germany & 15 & 6 \\
Italy & 19 & 4 \\
Japan & 7 & 2 \\
Switzerland & 34 & 6 \\
United Kingdom & 10 & 3 \\
United States & 23 & 4 \\
Rest of EC & 52 & 12 \\
Others & 4 & 1 \\
\end{tabular}

\section{Fellowships}

Country No. of fellows No. hosted

$\begin{array}{lll}\text { Canada } & 6 & 5\end{array}$

France

10

Germany

Italy

Japan

15

4

Switzerland

35

United Kingdom

5

United States

Rest of EC

21
15

17

Others

24 